\section{Heavy tamponade 1: a review of indications, use, and complications}

\author{
Abstract \\ Background Heavier than water intraocular \\ tamponades have several theoretical \\ advantages over conventional tamponades, \\ especially in the treatment of complicated \\ retinal detachments and proliferative \\ viteroretinopathy of the lower fundus \\ periphery. However, initial clinical series of \\ various heavy tamponades have reported \\ significant complication rates. Therefore, \\ heavy tamponades have not found widespread \\ acceptance. Three recently developed heavy \\ silicone oil tamponades, Oxane HD, Densiron \\ 68 , and HWS 46-3000, are much better tolerated \\ and presently seem to enter routine clinical \\ practice. \\ Materials and methods Literature review of \\ 21 publications on the clinical application of 9 \\ different heavy tamponades (fluorosilicone, \\ C10F18, F6H8, OL62HV, Oxane HD, O62, \\ F6H8-silicone oil mixture, Densiron 68, and \\ HWS 46-3000). \\ Results The first generation (fluorinated \\ silicone and perfluorocarbon liquids) and \\ second generation (partially fluorinated \\ alkanes) of heavy tamponades were associated \\ with relatively high complication rates, for \\ example, tamponade emulsification, \\ intraocular inflammation, and rise in \\ intraocular pressure. The complication \\ spectrum of the new generation of heavy \\ silicone oils (Oxane HD, Densiron 68, and \\ HWS 46-3000) seems to be comparable to \\ conventional silicone oil tamponades while \\ providing better support for the inferior retina \\ and the posterior pole. \\ Conclusion The recently developed \\ heavy silicone oil tamponades are safe \\ and effective tools for the use of complicated \\ retinal detachments of the inferior \\ fundus. \\ Eye (2008) 22, 1342-1359; doi:10.1038/eye.2008.61; \\ published online 14 March 2008
}

H Heimann, T Stappler and D Wong

Keywords: heavy tamponade; heavy silicone oil; proliferative vitreoretinopathy; retinal detachment

\section{Introduction}

Despite many advances over the past 30 years, there are still significant functional and anatomical challenges associated throughout the field of vitreoretinal surgery. Many of these lie in treating pathology that is located and at the posterior pole and especially in the lower fundus periphery. These are the two areas in which our standard gas or silicone oil endotamponades are unable to provide satisfactory retinal support in the usual upright and supine positions. A 'heavier than water' intraocular tamponade offers the potential to provide adequate support in these particular problem areas and has therefore 'long been very high on the wish list of vitreoretinal surgeons' ${ }^{1-3}$

The first heavy tamponades, fluorosilicone and perfluorocarbons, were introduced into clinical practise in the early 1990s. ${ }^{4-8}$ It soon emerged, however, that these substances could only be used intraoperatively and as a shortterm tamponade, too short a time that would have been needed to treat complicated cases of proliferative vitreoretinopathy (PVR). ${ }^{9,10}$ The next substance in use as a long-term heavy tamponade, one which achieved certification in Europe for several clinical studies in the early 2000s was perfluorohexyloctane (F6H8). While some authors found encouraging results, ${ }^{11,12}$ other groups reported a plethora of complications and discouraged the use of $\mathrm{F} 6 \mathrm{H} 8$ as a vitreous substitute. ${ }^{13-16}$ Around the same time, two new tamponades showed promising results in initial experimental settings, OL62HV and O62, only too soon to be associated with a high failure rate and massive complications. ${ }^{14,17}$ Double filling with F6H8 and silicone oil has also been tried to provide simultaneous 
superior and inferior tamponade but, as both substances merged, the resulting tamponade bubble proved less effective than expected. ${ }^{18,19}$

Following the relative disappointment with these early heavy tamponades, we now seem to have entered a phase in which we might see the introduction of these vitreous substitutes into routine clinical use. Three recently developed heavy tamponades, Oxane HD, Densiron 68 and HWS 46-3000, have demonstrated better results and fewer complications compared to the earlier used substances, ${ }^{20-22}$ and are now slowly gaining acceptance within the vitreoretinal community, ${ }^{23-27}$ despite notable scepticism. In this article, the previous and current heavy tamponades, their indications, and the associated complications are reviewed. More detailed information about the physical and chemical properties of intraocular tamponades has been published elsewhere. $^{28-30}$

\section{Requirements for a heavier than water tamponade}

For any substance to be effective as a tamponade, it must be immiscible with water with which it will form an interface. Interfacial tension between a tamponade (and water) is the energy derived from the van der Waal's interaction on the bubbles surface. The higher the interfacial tension, the greater is a substance's tendency to stay as a single bubble. This results in a lesser tendency for that particular substance to pass through a retinal break, for example. Tamponade leads to retinal reattachment in many ways. First, tamponades act by displacing aqueous. A tamponade agent that floats (or sinks) will displace pre-retinal and subretinal fluid from the upper (or lower) part of the fundus, thus opposing the retina. If there is no residual vitreoretinal traction, the retina and the retinal breaks will be opposed on the underlying retinal pigment epithelium. Second, if there was retinal traction, the retina might be partially detached and if there was a retinal break in the detached retina, a tamponade bubble could serve to occlude the break. The interfacial tension would prevent the tamponade going through the break; similarly, aqueous could not gain access to the subretinal space because the break was occluded. Lastly, the tamponade agent could act by totally filling the vitreous cavity, obliterating the space into which retinal detachments could occur. This last proposition is much harder to achieve in reality. Our model eye chamber showed that it is difficult to achieve a $100 \%$ fill simply because the cavity is rounded. ${ }^{31}$

\section{Presumed advantages of heavy tamponades}

The main target for heavy tamponades is more complicated situations of rhegmatogenous retinal detachments (RRDs) with large breaks or PVR in the lower periphery (Table 1). PVR remains the major complication associated with RRD surgery and the main reason for unsatisfactory anatomical and functional outcomes. Despite some progress seems to have been achieved regarding PVR rates over the past decades, ${ }^{36}$ there are also reports demonstrating no major differences in its incidence in a tertiary centre between 1988 and 2003. ${ }^{37}$ Medical adjunctive therapy so far has not found widespread acceptance, although two studies have shown beneficial effects of intravitreal application of daunorubicin ${ }^{38}$ or a combination of 5-fluorouracil and low molecular weight heparin. ${ }^{39}$ Therefore, the surgical technique remains the major option to prevent the development of postoperative PVR and remains the standard treatment once it has occurred.

In the majority of cases, advanced PVR is treated with pars plana vitrectomy, silicone oil, and additional scleral buckling or, less frequently, with long-acting gas tamponades or scleral buckling alone. With lighter than water tamponades, the superior periphery and the posterior pole can be supported in the usual upright position. However, no complete tamponade of the entire retinal area is possible. ${ }^{19}$ Therefore, there is no efficient tamponade in the lower fundus periphery and a mixture of aqueous humour and growth factors ('PVR soup') is concentrated here. Indeed, most reproliferations of PVR can be seen in these areas that are not covered by the silicone oil tamponade in the upright position. In the supine position, the PVR soup shifts to the pre-macular area, thereby enhancing the risk for formation of pre-macular epiretinal membranes and cystoid macular oedema.

The theoretical benefits of a heavy tamponade in such complicated retinal detachments are

(1) Breaks and retinotomy edges in the lower periphery can efficiently be supported in the upright position.

(2) The instantaneous interruption of an open communication between the subretinal space/retinal pigment epithelial cells and the pre-retinal space through the patent break might lower the risks for a PVR development and a reopening of the break.

(3) Displacement of the proliferative mixture of residual aqueous, inflammatory, and RPE cells away from lower retina and the posterior pole could result in a reduction of postoperative PVR and cystoid macular oedema.

(4) The tamponade effect at the posterior pole may lead to a faster and lasting reattachment of the macula.

(5) Redetachments should arise predominantly in the superior periphery where they are easier to treat with gas tamponades.

(6) Redetachments should have a higher percentage of 'macula on' situations. 
Table 1 Clinical studies of heavy tamponades

\begin{tabular}{|c|c|c|c|c|c|c|c|c|c|c|c|}
\hline $\begin{array}{l}\text { Author, } \\
\text { reference }\end{array}$ & Tamponade & Study design & $\begin{array}{l}\text { Inclusion } \\
\text { criteria }\end{array}$ & $\mathrm{N}$ & $\begin{array}{l}\text { Previous VR } \\
\text { surgery (\%) }\end{array}$ & Follow-up & $\begin{array}{l}\text { Time to } \\
\text { removal }\end{array}$ & $\begin{array}{l}\text { Anatomical } \\
\text { success }\end{array}$ & $\begin{array}{l}\text { Functional } \\
\text { outcome }\end{array}$ & Complications & $\begin{array}{l}\text { Authors' } \\
\text { impression }\end{array}$ \\
\hline $\begin{array}{l}\text { Gremillion } \\
\text { et } a l^{6}\end{array}$ & Fluorosilicone & $\begin{array}{l}\text { Consecutive } \\
\text { series, single } \\
\text { centre }\end{array}$ & $\begin{array}{l}\text { Complicated } \\
\text { RRD (PVR, } \\
\text { trauma, retinal } \\
\text { necrosis), } \\
\text { tractional RD } \\
\text { (diabetic } \\
\text { retinopathy) }\end{array}$ & 30 & 19/30 (63) & $\begin{array}{l}\text { Median } 6 \\
\text { months, range } \\
3-12\end{array}$ & 2-8 weeks & $\begin{array}{l}\text { Primary } 77 \% \\
(23 / 30) \\
\text { Final } 93 \% \\
(28 / 30)\end{array}$ & $\begin{array}{l}\text { Range no light } \\
\text { perception to } \\
\text { logMAR } 0.4\end{array}$ & $\begin{array}{l}\text { Emulsification } 100 \% \\
(30 / 30) \\
\text { AC inflammation } 10 \% \\
(3 / 30) \\
\text { Keratopathy } 10 \%(3 / 30) \\
\text { Cataract progression } 75 \% \\
(6 / 8) \\
\text { Rise in IOP 13\% }(4 / 30) \\
\text { Hypotony } 13 \%(4 / 30)\end{array}$ & $\begin{array}{l}\text { Fluorosilicone } \\
\text { may prove } \\
\text { useful as an } \\
\text { intraoperative } \\
\text { tool or } \\
\text { intermediate } \\
\text { vitreous } \\
\text { replacement as } \\
\text { the search for a } \\
\text { more permanent } \\
\text { substitute } \\
\text { continues }\end{array}$ \\
\hline Bottoni et $a l^{5}$ & C10F18 & $\begin{array}{l}\text { Consecutive } \\
\text { series, single } \\
\text { centre }\end{array}$ & $\begin{array}{l}\text { Complicated } \\
\text { RRD (PVR, giant } \\
\text { tears, trauma) }\end{array}$ & 32 & $8 / 32(25)$ & $\begin{array}{l}\text { Median } 8 \\
\text { months, range } \\
4-12\end{array}$ & 5 days $^{\mathrm{a}}$ & $\begin{array}{l}\text { Primary 25/32 } \\
(72 \%) \\
\text { Final } 27 / 32(84 \%)\end{array}$ & $\begin{array}{l}17 / 32(68 \%) \\
\log M A R \geqslant 1.0\end{array}$ & $\begin{array}{l}\text { Rise in IOP } 81 \%(26 / 32) \\
\text { Pupillary membranes } \\
28 \%(9 / 32) \\
\text { Corneal opacification } 9 \% \\
\text { (3/32) } \\
\text { Residual emulsification 9\% } \\
(3 / 32) \\
\text { Hypotony 3\% (1/32) } \\
\text { PVR 39\% (12/32) }\end{array}$ & $\begin{array}{l}\text { Larger study } \\
\text { is needed }\end{array}$ \\
\hline $\begin{array}{l}\text { Kirchhof } \\
\text { et } a l^{11}\end{array}$ & $\mathrm{~F} 6 \mathrm{H} 8$ & $\begin{array}{l}\text { Consecutive } \\
\text { series, three } \\
\text { centres }\end{array}$ & $\begin{array}{l}\text { Complicated } \\
\text { RRD (PVR, giant } \\
\text { tears, hypotony), } \\
\text { tractional RD } \\
\text { (diabetic } \\
\text { retinopathy) }\end{array}$ & 23 & $21 / 23(93)$ & $\begin{array}{l}4 \text { weeks after } \\
\text { F6H8 removal }\end{array}$ & $\begin{array}{l}\text { Mean } 76 \\
\text { days, } \\
\text { SD } 37.6\end{array}$ & $\begin{array}{l}\text { Primary } 19 / 22 \\
(86 \%)^{\mathrm{b}} \\
\text { Final } 18 / 19(95 \%)^{\mathrm{c}}\end{array}$ & $\begin{array}{l}\text { logMAR (mean, } \\
\text { SD) } 1.58,0.86^{c}\end{array}$ & $\begin{array}{l}\text { Cataract progression in } \\
90 \%(9 / 19) \text { of phakic } \\
\text { patients } \\
\text { Pupillary block } 9 \%(2 / 23) \\
\text { Moderate AC } \\
\text { inflammation } 9 \%(2 / 23) \\
\text { Dispersion } 52 \%(12 / 23)\end{array}$ & $\begin{array}{l}\text { F6H8 is } \\
\text { tolerated in the } \\
\text { human eye for } \\
\text { extended } \\
\text { periods }\end{array}$ \\
\hline Roider $e$ a $a l^{14}$ & $\mathrm{~F} 6 \mathrm{H} 8$ & $\begin{array}{l}\text { Consecutive } \\
\text { series, two } \\
\text { centres }\end{array}$ & $\begin{array}{l}\text { Complicated } \\
\text { RRD (PVR, } \\
\text { trauma), } \\
\text { tractional RD } \\
\text { (diabetic } \\
\text { retinopathy) }\end{array}$ & 5 & $2 / 5$ & $\begin{array}{l}6 \text { months after } \\
\text { tamponade } \\
\text { removal }\end{array}$ & 4-6 weeks & $\begin{array}{l}\text { Primary } 3 / 5 \\
\text { Final } 5 / 5,2 \text { with } \\
\text { silicone oil }\end{array}$ & $\begin{array}{l}\text { logMAR range } \\
1.5-0.4\end{array}$ & $\begin{array}{l}\text { Dispersion } 2 / 5 \\
\text { Marked rise in IOP } 1 / 5 \\
\text { Corneal opacity } 2 / 5 \\
\text { Fluffy precipitates } 2 / 5\end{array}$ & $\begin{array}{l}\text { Further animal } \\
\text { testing is } \\
\text { required }\end{array}$ \\
\hline Roider $e$ a $a l^{14}$ & OL62HV & $\begin{array}{l}\text { Prospective } \\
\text { clinical trial, } \\
\text { two centres }\end{array}$ & $\begin{array}{l}\text { RRD with breaks } \\
\text { in the lower } \\
\text { periphery } \\
\text { (retinoschisis, } \\
\text { BRVO, } \\
\text { redetachment) }\end{array}$ & 4 & $2 / 4$ & $\begin{array}{l}6 \text { months after } \\
\text { tamponade } \\
\text { removal }\end{array}$ & 4-6 weeks & $\begin{array}{l}\text { Final } 3 / 4 \text { with } \\
\text { silicone oil }\end{array}$ & $\begin{array}{l}\text { Range no } \\
\text { perception of } \\
\text { light to } \\
\text { logMAR } 0.6\end{array}$ & $\begin{array}{l}\text { Severe fibrin reaction } \\
1 / 4 \\
\text { Extensive fluffy } \\
\text { precipitates } 4 / 4 \\
\text { Retinal necrosis } 2 / 4 \\
\text { Severe PVR } 4 / 4\end{array}$ & $\begin{array}{l}\text { Trial stopped } \\
\text { prematurely, } \\
\text { OL62HV is not } \\
\text { suitable as a } \\
\text { tamponade }\end{array}$ \\
\hline $\begin{array}{l}\text { Stefaniotou } \\
\text { et } a l^{12}\end{array}$ & F6H8 & $\begin{array}{l}\text { Consecutive } \\
\text { series, single } \\
\text { centre }\end{array}$ & $\begin{array}{l}\text { Complicated } \\
\text { RRD (PVR, } \\
\text { macular hole, } \\
\text { trauma) }\end{array}$ & 14 & $5 / 14(36)$ & $\begin{array}{l}\text { Mean } 6 \\
\text { months, range } \\
3-12\end{array}$ & 3-8 weeks & $\begin{array}{l}\text { Primary } 10 / 14 \\
(71 \%) \\
\text { Final } 12 / 14(86 \%)\end{array}$ & $\begin{array}{l}\text { Median logMAR } \\
0.5, \text { range NPL } \\
\text { to } 0.2\end{array}$ & $\begin{array}{l}\text { Cataract progression } \\
78 \%(7 / 9) \\
\text { F6H8 in the AC } 29 \% \\
(4 / 14) \\
\text { Phtisis } 7 \%(1 / 14)\end{array}$ & $\begin{array}{l}\text { Promising } \\
\text { tamponade } \\
\text { agent }\end{array}$ \\
\hline
\end{tabular}


Table 1 (Continued)

\begin{tabular}{|c|c|c|c|c|c|c|c|c|c|c|c|}
\hline $\begin{array}{l}\text { Author, } \\
\text { reference }\end{array}$ & Tamponade & Study design & $\begin{array}{l}\text { Inclusion } \\
\text { criteria }\end{array}$ & $\mathrm{N}$ & $\begin{array}{l}\text { Previous VR } \\
\text { surgery (\%) }\end{array}$ & Follow-up & $\begin{array}{l}\text { Time to } \\
\text { removal }\end{array}$ & $\begin{array}{l}\text { Anatomical } \\
\text { success }\end{array}$ & $\begin{array}{l}\text { Functional } \\
\text { outcome }\end{array}$ & Complications & $\begin{array}{l}\text { Authors' } \\
\text { impression }\end{array}$ \\
\hline \multirow[t]{2}{*}{ Vote et $a l^{16}$} & F6H8 & $\begin{array}{l}\text { Retrospective, } \\
\text { single centre }\end{array}$ & $\begin{array}{l}\text { Inferior RRD } \\
\text { (PVR, presumed } \\
\text { endophthalmitis) }\end{array}$ & 5 & $2 / 5$ & 3-6 months & $\begin{array}{l}2 \text { days to } 9 \\
\text { weeks }\end{array}$ & $\begin{array}{l}\text { Primary } 1 / 5 \\
\text { Final } 5 / 5\end{array}$ & $\begin{array}{l}\text { Range } \\
\text { logMAR } 0.7-0.3\end{array}$ & $\begin{array}{l}\text { Corneal opacification } 1 / 5 \\
\text { Posterior segment } \\
\text { precipitates and } \\
\text { inflammation } 2 / 5 \\
\text { PVR membranes } 3 / 5 \\
\text { Subretinal F6H8 } 1 / 5 \\
\text { Emulsification } 1 / 5\end{array}$ & \\
\hline & & & & & & & & $\begin{array}{l}\text { Recommendation } \\
\text { against the use of } \\
\text { F6H8 }\end{array}$ & & & \\
\hline Wolf $e t a l^{20}$ & Oxane HD & $\begin{array}{l}\text { Consecutive } \\
\text { series, one } \\
\text { centre }\end{array}$ & $\begin{array}{l}\text { Complicated } \\
\text { RRD (PVR, giant } \\
\text { tears, posterior } \\
\text { tears, trauma) }\end{array}$ & 33 & $31 / 33(94)$ & $\begin{array}{l}12 \text { months } \\
\text { following } \\
\text { Oxane HD } \\
\text { insertion, } \\
\text { range 12-16 }\end{array}$ & $\begin{array}{l}\text { Within } 3 \\
\text { months }\end{array}$ & $\begin{array}{l}\text { Primary } \\
19 / 33(58 \%) \\
\text { Final 31/33 }(94 \%)^{\mathrm{d}}\end{array}$ & $\begin{array}{l}25 / 33(81 \%) \\
\text { logMAR } \geqslant 1.3, \\
\text { range NPL to } 0.5\end{array}$ & $\begin{array}{l}\text { Rise in IOP } 6 / 33(18 \%) \\
\text { Pupillary block } 2 / 33(6 \%) \\
\text { Marked AC inflammation } \\
3 \%(1 / 33) \\
\text { Retinal haemorrhages } 6 \% \\
(2 / 33)\end{array}$ & $\begin{array}{l}\text { Heavy silicone } \\
\text { oil can be used } \\
\text { as an effective } \\
\text { endotamponade } \\
\text { in complicated } \\
\text { retinal } \\
\text { detachment }\end{array}$ \\
\hline $\begin{array}{l}\text { Gerding and } \\
\text { Kolck }^{13}\end{array}$ & F6H8 & $\begin{array}{l}\text { Consecutive } \\
\text { series, one } \\
\text { centre }\end{array}$ & $\begin{array}{l}\text { Complicated } \\
\text { retinal } \\
\text { redetachment } \\
\text { (PVR, trauma, } \\
\text { endophthalmitis, } \\
\text { retinopathy of } \\
\text { prematurity) }\end{array}$ & 17 & $17 / 17(100)$ & $\begin{array}{l}6 \text { months after } \\
\text { F6H8 removal }\end{array}$ & $\begin{array}{l}\text { Median } 25 \\
\text { days, range } \\
21-25\end{array}$ & Final $71 \%(12 / 17)$ & $\begin{array}{l}\text { logMAR (mean, } \\
\text { range) } 1.7,0.7-2.1\end{array}$ & $\begin{array}{l}\text { Dispersion } 17 / 17(100 \%) \\
\text { Corneal edema } 6 / 17(35 \%) \\
\text { Fibrinous AC } \\
\text { inflammation } 35 \%(6 / 17) \\
\text { Cataract progression } 75 \% \\
(3 / 4) \\
\text { Marked posterior capsular } \\
\text { fibrosis } 47 \%(8 / 17) \\
\text { Hypotony } 81 \%(13 / 16) \\
\text { Precipitates on posterior } \\
\text { lens surface } 41 \%(7 / 17) \\
\text { Fluffy precipitates } 100 \% \\
(17 / 17)\end{array}$ & $\begin{array}{l}\text { F6H8 as long- } \\
\text { term tamponade } \\
\text { not } \\
\text { recommended } \\
\text { because of the } \\
\text { high rate of } \\
\text { postoperative } \\
\text { hypotony }\end{array}$ \\
\hline Schatz et $a l^{15}$ & F6H8 & $\begin{array}{l}\text { Consecutive } \\
\text { series, single } \\
\text { centre }\end{array}$ & $\begin{array}{l}\text { Complicated } \\
\text { RRD (PVR, } \\
\text { multiple breaks), } \\
\text { tractional RD } \\
\text { (diabetic } \\
\text { retinopathy) }\end{array}$ & 18 & $16 / 18(89)$ & e & $\begin{array}{l}\text { Median } 8 \\
\text { weeks, range } \\
2-14\end{array}$ & $\begin{array}{l}\text { Primary } 10 / 18 \\
(56 \%) \\
\text { Final } 15 / 18(83 \%)\end{array}$ & $\begin{array}{l}\text { Range no light } \\
\text { perception to } \\
\text { logMAR } 0.3\end{array}$ & $\begin{array}{l}\text { Corneal damage 33\% (6/ } \\
\text { 18) } \\
\text { Fibrinous AC } \\
\text { inflammation } 28 \%(5 / 18 \\
\text { Hypotony } 11 \%(2 / 18) \\
\text { Phtisis } 11 \%(2 / 18) \\
\text { Dispersion } 6 \%(1 / 18)\end{array}$ & $\begin{array}{l}\text { F6H8 has not } \\
\text { been tolerated } \\
\text { well as a long- } \\
\text { term } \\
\text { tamponade; } \\
\text { should be } \\
\text { limited for } \\
\text { complicated } \\
\text { cases of the } \\
\text { inferior retina }\end{array}$ \\
\hline Theelen $e t a l^{27}$ & Oxane HD & $\begin{array}{l}\text { Consecutive } \\
\text { series, one } \\
\text { centre }\end{array}$ & $\begin{array}{l}\text { Complicated } \\
\text { RRD (PVR, large } \\
\text { breaks) }\end{array}$ & 19 & $14 / 19$ (74) & $\begin{array}{l}\text { Mean } 3 \text { months } \\
\text { after Oxane } \\
\text { HD removal, } \\
\text { range } 2-4\end{array}$ & $\begin{array}{l}\text { Mean } 2 \\
\text { months, } \\
\text { range 1-4 }\end{array}$ & $\begin{array}{l}\text { Primary 17/19 } \\
(89 \%)\end{array}$ & & $\begin{array}{l}\text { Keratic precipitates } 37 \% \\
(7 / 19) \\
\text { Emulsification } 11 \%(2 / 19)\end{array}$ & $\begin{array}{l}\text { Additional } \\
\text { clinical trials are } \\
\text { necessary before } \\
\text { routine use can } \\
\text { be recommended }\end{array}$ \\
\hline
\end{tabular}


Table 1 (Continued)

\begin{tabular}{|c|c|c|c|c|c|c|c|c|c|c|c|}
\hline $\begin{array}{l}\text { Author, } \\
\text { reference }\end{array}$ & Tamponade & Study design & $\begin{array}{l}\text { Inclusion } \\
\text { criteria }\end{array}$ & $\mathrm{N}$ & $\begin{array}{l}\text { Previous VR } \\
\text { surgery (\%) }\end{array}$ & Follow-up & $\begin{array}{l}\text { Time to } \\
\text { removal }\end{array}$ & $\begin{array}{l}\text { Anatomical } \\
\text { success }\end{array}$ & $\begin{array}{l}\text { Functional } \\
\text { outcome }\end{array}$ & Complications & $\begin{array}{l}\text { Authors' } \\
\text { impression }\end{array}$ \\
\hline Hoerauf et $a l^{17}$ & $\mathrm{O} 62$ & $\begin{array}{l}\text { Consecutive } \\
\text { series, one } \\
\text { centre }\end{array}$ & $\begin{array}{l}\text { Complicated } \\
\text { RRD (PVR, giant } \\
\text { tears, } \\
\text { retinoschisis) }\end{array}$ & 11 & 9/11 (81) & $\begin{array}{l}\text { Median } 16 \\
\text { months after } \\
\text { O62 removal }\end{array}$ & $\begin{array}{l}\text { Median } 43 \\
\text { days, range } \\
17-55\end{array}$ & $\begin{array}{l}\text { Primary } 7 / 11 \\
(63 \%) \\
\text { Final } 11 / 11(100 \%)\end{array}$ & $\begin{array}{l}\log M A R(\text { median}) \\
0.7\end{array}$ & $\begin{array}{l}\text { AC inflammation } 100 \% \\
(11 / 11) \\
\text { Temporary rise in IOP } \\
18 \%(2 / 11) \\
\text { Severe emulsification } \\
100 \%(11 / 11)\end{array}$ & $\begin{array}{l}\text { O62 is not } \\
\text { suitable as long- } \\
\text { term intraocular } \\
\text { tamponade }\end{array}$ \\
\hline Rizzo et $a l^{32}$ & Oxane HD & $\begin{array}{l}\text { Consecutive } \\
\text { series, single } \\
\text { centre }\end{array}$ & $\begin{array}{l}\text { Complicated } \\
\text { RRD (PVR, } \\
\text { posterior breaks, } \\
\text { giant tears, } \\
\text { choroidal } \\
\text { detachment, } \\
\text { trauma) }\end{array}$ & 28 & $25 / 28(89)$ & $\begin{array}{l}6 \text { months after } \\
\text { tamponade } \\
\text { removal }\end{array}$ & $\begin{array}{l}88 \text { days, } \\
\text { range } 45-96\end{array}$ & $\begin{array}{l}\text { Primary } 54 \%(15 / \\
28)\end{array}$ & $\begin{array}{l}\text { logMAR (mean) } \\
1.5 \text {, range } 2.3-0.4\end{array}$ & $\begin{array}{l}\text { Cataract progression } 38 \% \\
(3 / 8) \\
\text { Rise in IOP } 14 \%(4 / 28) \\
\text { Tamponade in AC } 4 \% \\
(1 / 28) \\
\text { Membrane formation } 54 \% \\
(15 / 28)\end{array}$ & $\begin{array}{l}\text { Good } \\
\text { intraocular } \\
\text { tolerance with } \\
\text { few minor } \\
\text { complications } \\
\text { and } \\
\text { encouraging } \\
\text { success rate } \\
\text { without indent }\end{array}$ \\
\hline Rizzo et $a l^{33}$ & $\begin{array}{l}\text { Sequential } \\
\text { injection of 30\% } \\
\text { F6H8 and } 70 \% \\
\text { silicone oil } \\
1000 \mathrm{cSt}\end{array}$ & $\begin{array}{l}\text { Consecutive } \\
\text { series, seven } \\
\text { centres }\end{array}$ & $\begin{array}{l}\text { Primary RRD } \\
\text { (PVR, giant tears, } \\
\text { multiple tears) }\end{array}$ & 28 & None & $\begin{array}{l}6 \text { months after } \\
\text { tamponade } \\
\text { removal }\end{array}$ & $\begin{array}{l}41 \text { days, } \\
\text { range } 30-45\end{array}$ & $\begin{array}{l}\text { Primary } 21 / 28 \\
(75 \%)\end{array}$ & $\begin{array}{l}\text { Range LP to } \\
\text { logMAR } 0.3\end{array}$ & $\begin{array}{l}\text { Fibrinous AC } \\
\text { inflammation } 4 \%(1 / 28) \\
\text { Emulsification } 7 \%(2 / 28) \\
\text { IOP rise } 36 \%(10 / 28)\end{array}$ & $\begin{array}{l}\text { May be a useful } \\
\text { tool in the } \\
\text { treatment of } \\
\text { complicated } \\
\text { RRD }\end{array}$ \\
\hline Rizzo et $a l^{33}$ & $\begin{array}{l}\text { Sequential } \\
\text { injection of 30\% } \\
\text { F6H8 and 70\% } \\
\text { silicone oil } \\
1000 \mathrm{cSt}\end{array}$ & $\begin{array}{l}\text { Consecutive } \\
\text { series, seven } \\
\text { centres }\end{array}$ & $\begin{array}{l}\text { Complicated } \\
\text { redetachment } \\
\text { (PVR, giant tears, } \\
\text { multiple tears) }\end{array}$ & 41 & $41 / 41(100)$ & $\begin{array}{l}6 \text { months after } \\
\text { tamponade } \\
\text { removal }\end{array}$ & $\begin{array}{l}38 \text { days, } \\
\text { range } 30-45\end{array}$ & $\begin{array}{l}\text { Primary } 28 / 41 \\
(68 \%)\end{array}$ & $\begin{array}{l}\text { Range LP to } \\
\text { logMAR } 0.3\end{array}$ & $\begin{array}{l}\text { Fibrinous AC } \\
\text { inflammation } 5 \%(2 / 41) \\
\text { Emulsification } 40 \%(16 / \\
41) \\
\text { IOP rise } 39 \%(16 / 41)\end{array}$ & \\
\hline Tognetto et $a l^{34}$ & $\begin{array}{l}\text { Mixture of } 30 \% \\
\text { F6H8 and } 70 \% \\
\text { silicone oil } \\
1000 \text { cSt }\end{array}$ & $\begin{array}{l}\text { Consecutive } \\
\text { series, one } \\
\text { centre }\end{array}$ & $\begin{array}{l}\text { RRD with PVR } \\
\text { grade C } \\
\text { (including giant } \\
\text { tear, macular } \\
\text { hole, trauma) }\end{array}$ & 26 & $21 / 26(81)$ & $\begin{array}{l}10 \text { months after } \\
\text { removal }\end{array}$ & 60 days & $\begin{array}{l}\text { Primary } 24 / 26 \\
(62 \%) \\
\text { Final } 26 / 26(100 \%)\end{array}$ & $\begin{array}{l}18 / 26(69 \%) \\
\geqslant \log \text { MAR } 1.3\end{array}$ & $\begin{array}{l}\text { Acute IOP rise } 12 \% \\
(3 / 26) \\
\text { IOP rise (total) } 31 \% \\
(8 / 26) \\
\text { Hypotension } 4 \%(1 / 26) \\
\text { Dispersion } 4 \%(1 / 26)\end{array}$ & $\begin{array}{l}\text { Very promising } \\
\text { heavy } \\
\text { tamponade }\end{array}$ \\
\hline Wong et $a l^{21}$ & Densiron 68 & $\begin{array}{l}\text { Prospective, } \\
\text { two centres }\end{array}$ & $\begin{array}{l}\text { Complicated } \\
\text { RRD (PVR, } \\
\text { inferior and } \\
\text { posterior breaks) }\end{array}$ & 42 & $26 / 42(62)$ & $\begin{array}{l}\geqslant 3 \text { months } \\
\text { after removal }\end{array}$ & $10-16$ weeks & $\begin{array}{l}\text { Primary } 81 \%(34 / \\
42) \\
\text { Final } 93 \%(39 / 42)\end{array}$ & $\begin{array}{l}\text { logMAR (mean, } \\
\text { SD) } 0.94,0.57 \\
\text { Improvement } \\
66 \%\end{array}$ & $\begin{array}{l}\text { Cataract progression } \\
\text { in all phakic patients } \\
\text { IOP > } 30 \mathrm{mmHg} \text { in } 8 \% \\
(3 / 42) \text { at the end of study } \\
\text { Moderate AC } \\
\text { inflammation in } 8 \% \\
(3 / 42)\end{array}$ & $\begin{array}{l}\text { Densiron may } \\
\text { add to our } \\
\text { repertoire in } \\
\text { managing } \\
\text { selected retinal } \\
\text { detachments }\end{array}$ \\
\hline
\end{tabular}


Table 1 (Continued)

\begin{tabular}{|c|c|c|c|c|c|c|c|c|c|c|c|}
\hline $\begin{array}{l}\text { Author, } \\
\text { reference }\end{array}$ & Tamponade & Study design & $\begin{array}{l}\text { Inclusion } \\
\text { criteria }\end{array}$ & $\mathrm{N}$ & $\begin{array}{l}\text { Previous VR } \\
\text { surgery (\%) }\end{array}$ & Follow-up & $\begin{array}{l}\text { Time to } \\
\text { removal }\end{array}$ & $\begin{array}{l}\text { Anatomical } \\
\text { success }\end{array}$ & $\begin{array}{l}\text { Functional } \\
\text { outcome }\end{array}$ & Complications & $\begin{array}{l}\text { Authors' } \\
\text { impression }\end{array}$ \\
\hline $\begin{array}{l}\text { Sandner and } \\
\text { Engelmann }^{25}\end{array}$ & Densiron 68 & $\begin{array}{l}\text { Consecutive } \\
\text { series, one } \\
\text { centre }\end{array}$ & $\begin{array}{l}\text { RRD with PVR, } \\
\text { previous trauma, } \\
\text { endophthalmitis }\end{array}$ & 48 & 48/48 (100) & $\begin{array}{l}\text { Mean } 103 \text { days } \\
\text { following } \\
\text { removal, SD } \\
31.9 \text { days }\end{array}$ & $\begin{array}{l}\text { Mean } 108 \\
\text { days, SD } \\
66.9, \text { range } \\
27-400\end{array}$ & $\begin{array}{l}\text { Primary } 46 \%(22 / \\
48) \\
\text { Final 92\% (44/48) }\end{array}$ & $\begin{array}{l}\text { logMAR (mean, } \\
\text { SD) } 1.47,0.97\end{array}$ & $\begin{array}{l}\text { Dispersion } 16 \% \\
(6 / 42) \text { at } 1 \text { month } \\
\text { Emulsification } 15 \%(7 / 48) \\
\text { Ischaemic optic } \\
\text { neuropathy } 2 \%(1 / 48) \\
\text { Hypotony } 2 \%(1 / 48) \\
\text { Moderate AC } \\
\text { inflammation } 21 \%(10 / 48) \\
\text { Sterile hypopyon } 4 \% \\
(4 / 48) \\
\text { Persistent IOP elevation } \\
10 \%(5 / 48) \\
\text { Ocular hypotension } 13 \% \\
(6 / 48) \\
\text { Cataract progression } 50 \% \\
(4 / 8)\end{array}$ & $\begin{array}{l}\text { The use of } \\
\text { Densiron has } \\
\text { proven to be } \\
\text { well worth } \\
\text { further } \\
\text { evaluation }\end{array}$ \\
\hline Cheung et $a l^{35}$ & Oxane HD & $\begin{array}{l}\text { Prospective } \\
\text { series, one } \\
\text { centre }\end{array}$ & $\begin{array}{l}\text { RRD in high } \\
\text { myopia and } \\
\text { macular hole }\end{array}$ & 12 & None & $\begin{array}{l}\text { Mean } 12 \\
\text { months, range } \\
9-15\end{array}$ & 3-4 months & $\begin{array}{l}\text { Primary } 83 \%(10 / \\
12) \\
\text { Final 92\% (11/12) }\end{array}$ & $\begin{array}{l}\text { logMAR (mean, } \\
\text { range) } 1.5, \mathrm{HM} \\
\text { to } 1.0\end{array}$ & $\begin{array}{l}\text { Rise in IOP } 42 \%(5 / 12) \\
\text { Emulsification } 8 \%(1 / 12)\end{array}$ & $\begin{array}{l}\text { Promising } \\
\text { vitreous } \\
\text { substitute in } \\
\text { RRD secondary } \\
\text { to myopic } \\
\text { macular hole }\end{array}$ \\
\hline Rizzo $e t a l^{22}$ & HWS 46-3000 & $\begin{array}{l}\text { Prospective, } \\
\text { single centre }\end{array}$ & $\begin{array}{l}\text { Complicated } \\
\text { RRD (PVR, } \\
\text { inferior and } \\
\text { posterior breaks) }\end{array}$ & 32 & 28/32 (88) & $\begin{array}{l}\text { Between } 1 \text { and } \\
3 \text { months }\end{array}$ & 6 months & $\begin{array}{l}\text { Primary } 84 \% \\
(27 / 32) \\
\text { Final 100\% (32/32) }\end{array}$ & $\begin{array}{l}\text { Mean logMAR 1.1, } \\
\text { range 3-0.1 }\end{array}$ & $\begin{array}{l}\text { Cataract progression } \\
100 \%(7 / 7) \\
\text { Rise in IOP 3\% (1/32) } \\
\text { Epiretinal membrane 9\% } \\
(3 / 32)\end{array}$ & $\begin{array}{l}\text { Useful tool in } \\
\text { complicated } \\
\text { RRD }\end{array}$ \\
\hline Sandner $e t a l^{26}$ & Densiron 68 & $\begin{array}{l}\text { Consecutive } \\
\text { series, one } \\
\text { centre }\end{array}$ & $\begin{array}{l}\text { Primary RRD } \\
\text { with PVR, RRD } \\
\text { with macular } \\
\text { hole }\end{array}$ & 12 & None & $\begin{array}{l}\text { Mean } 400 \text { days } \\
\text { following } \\
\text { removal, SD } \\
85.4\end{array}$ & $\begin{array}{l}\text { Mean } 78 \\
\text { days, SD } \\
29.7, \text { range } \\
33-126\end{array}$ & $\begin{array}{l}\text { Primary } 33 \% \\
(4 / 12) \\
\text { Final } 75 \%(9 / 12)\end{array}$ & $\begin{array}{l}\text { logMAR (mean, } \\
\text { SD) } 1.87,1.32\end{array}$ & $\begin{array}{l}\text { Emulsification } 17 \%(2 / 12) \\
\text { Moderate AC } \\
\text { inflammation } 33 \%(4 / 12) \\
\text { Suspected intraretinal } \\
\text { gliosis } 25 \%(3 / 12) \\
\text { Persistent IOP elevation } \\
17 \%(2 / 12) \\
\text { Ocular hypotension } 8 \% \\
(1 / 12) \\
\text { Cataract progression in } \\
3 / 3 \text { patients }\end{array}$ & $\begin{array}{l}\text { Our results are } \\
\text { less } \\
\text { encouraging } \\
\text { than those } \\
\text { reported in } \\
\text { other studies }\end{array}$ \\
\hline
\end{tabular}

${ }^{\mathrm{a} C} \mathrm{C} 10 \mathrm{~F} 18$-silicone oil exchange in $27 / 32$ eyes (84\%) after 5 days.

'One patient that was lost to follow-up was not included.

cFour patients lost to follow-up was not included.

${ }^{\mathrm{d}}$ Numbers recalculated from tables provided in the article, 15/31 patients had conventional silicone oil tamponade in place at the final 12-month follow-up visit.

${ }^{\mathrm{e}}$ Data are not provided in the article. 


\section{Substances used as heavy tamponades}

It is important to note that several different heavier than water tamponades have been used in clinical trials (Table 1). They differ significantly in their ability to make contact with the inner surface of the vitreous cavity, determined by the substances' specific gravity and interfacial tensions, and their viscosity that is critical to maintain the integrity of the tamponade over a longer period of time. ${ }^{19}$ Some of the current hesitation to use heavy tamponades is due to the high complication rates that have been reported with the use of the first generation of heavy tamponades. In recent years, a marked decrease in the complication rate and an improvement in the anatomical and functional outcomes could be achieved with the introduction of new heavy tamponades, in particular new heavy silicone oils.

\section{Fluorinated silicone and perfluorocarbon liquids}

Fluorinated silicone oil and perfluorocarbon liquids (PFCLs) were initially used as intraoperative tools to unfold and stabilise the retina during surgical manipulations. ${ }^{40,41}$ In a significant number of patients, the PFCL liquid cannot be removed completely and residual PFCL bubbles may remain intraocularly; these bubbles seem to be well tolerated over a longer period of time without major inflammatory reactions. ${ }^{5}$ Following these initial observations, several small series using 1000 and $300 \mathrm{cSt}$ fluorosilicone, ${ }^{6,8}$ perfluorodecalin $(\mathrm{C} 10 \mathrm{~F} 18){ }^{5}$ and perfluorophenanthrene ('Vitreon', C14F24) 5,7 as short- or long-term postoperative tamponades were published. The initial clinical series showed high complication rates (Table 1), the most striking being clinically visible emulsification in $100 \%$ of cases with fluorosilicone, a rise in intraocular pressure (IOP) in $81 \%$ with longer term PFCL tamponade, and corneal opacifications., ${ }^{5,6}$ In addition, a direct biological reaction to the tamponade substance was suspected and it was speculated that these tamponades might 'alter the blood-retina barrier' ${ }^{6}$ Case reports of long-term tamponades with PFCL have reported an extensive destruction of the retinal architecture and a marked reduction in the number of retinal cells. ${ }^{42}$ Other authors have found a good tolerance in a subset of patients with a longer intraocular PFCL tamponade. ${ }^{7}$ However, the anatomical and functional results ${ }^{5,7,43}$ could not demonstrate a meaningful advantage over standard surgical techniques. In addition, PFCL has to be replaced by a conventional long-term tamponade in the majority of patients to maintain retinal reattachment. ${ }^{43}$ Therefore, the use of these agents as postoperative tamponades is currently limited to few centres and shortterm tamponades only and has not met with widespread acceptance.

\section{Partially fluorinated alkanes and alkenes}

Partially fluorinated or semifluorinated alkanes (PFAs) were initially used as intraoperative tools to unfold the retina and as a solvent to remove silicone oil remnants from intraocular surfaces. ${ }^{44}$ Because they are physically, chemically, and physiologically inert and lighter than PFCL, a less pronounced biological reaction compared to PFCL as a postoperative tamponade was expected. F6H8 was the first PFA that was used as a long-term heavy tamponade in several clinical trials (Table 1). ${ }^{11-16}$ It was left intraocularly up to 14 weeks; on average, F6H8 was removed around 8 weeks postoperatively (Table 1 ). Marked differences in the complications and results of individual cases within one series ${ }^{15,16}$ as well between different series have been reported. Some authors describe very encouraging results with acceptable complication rates, ${ }^{11,12}$ whereas other authors found massive complications and discourage the use of F6H8 as a long-term tamponade. ${ }^{13-16}$ The major problems associated with this tamponade were emulsification in up to $100 \%$ of all cases; this, in consequence, was thought to initiate a inflammatory response characteristic of F6H8 tamponades and possibly a direct foreign body reaction to the emulsified droplets, ${ }^{13,16}$ although other authors could not find a major difference in the histology of intraocular membranes following $\mathrm{F} 6 \mathrm{H} 8$ compared to standard silicone oil tamponades. ${ }^{45}$ The routine use of F6H8 in the meantime has been superseded by the newer heavy tamponades as described below.

Perfluorohexylethan (O62) and the high-viscosity oligomer OL62HV are two additional PFAs that were used in clinical trial studies. ${ }^{14,17}$ The use of these substances was associated with the highest complication rates to be reported in clinical trials of heavy tamponades to date, including a $100 \%$ emulsification and anterior chamber inflammation rate, severe PVR reactions, and retinal necrosis. ${ }^{14,17}$ The use of these substances has, therefore, not been investigated any further.

\section{Double filling with F6H8 and silicone oil}

F6H8 and silicone oil have been used together as 'double filling'. The concept is that the two liquids, one that floats and one that sinks will provide simultaneous superior and inferior tamponade. F6H8 is soluble in silicone oil to a limited extent. When the two liquids are in contact, there is no interface between them. Tognetto et $a l^{34}$ used F6H8 with 1000 cSt silicone oil at a ratio of $3: 7$ in a syringe before intraocular injection. The tamponade was removed after 60 days in 26 patients. With a follow-up of 10 months, the results of this study are encouraging with fewer complications compared to the use of F6H8 alone. In a multi-centre study, Rizzo et $a l^{33}$ used the sequential 
injection of 30\% F6H8 and 70\% $1000 \mathrm{cSt}$ silicone oil in a total of 68 patients. The tamponade was removed after a mean of 40 days with a follow-up of 6 months after tamponade removal. Although an emulsification could be seen in a significant number of patients, especially in those with a more complicated anatomical situation, the anatomical and functional results were encouraging and the complications seem to be lower compared to F6H8 tamponade alone.

The concept of simultaneous superior and inferior tamponade is fundamentally flawed. It is important to understand that double filling is not a homogenous solution. The amount of F6H8 is much more than that can be dissolved in silicone oil. The top of the bubble might be silicone that is saturated with dissolved F6H8 and the lower part of the bubble is pure F6H8. This nonhomogenous mixture behaves as a single bubble with a specific gravity greater than water. The profile of this heavier than water bubble is 'egg-shaped' and as such that it might not provide good tamponade superiorly. The presence of silicone oil above, however, might inhibit dispersion by the F6H8. ${ }^{46}$ There are other problems. Because the silicone oil is virtually saturated with F6H8, and this solubility is temperature dependent, the silicone can turn cloudy when the patient is exposed to the cold or when the body is subjected to agitation by eye movements; the cloudiness is caused by droplets of F6H8 coming out of solution. This cloudiness is sufficient to interfere with vision and to impair fundal view. ${ }^{32}$

Double filling has been tried with fluorinated silicone and conventional silicone. ${ }^{47}$ When redetachment occurred, it occupied a 'new space horizontally between the bubbles and expanding in a triangular shape nasally to the optic disk and temporally to the macula' ${ }^{48}$

\section{Heavy silicone oils}

Recent developments aim at achieving more stable combinations of silicone oils and heavy liquids. The 'next generation' $^{22}$ of heavy tamponades currently consists of three different prefabricated mixtures-Oxane HD, Densiron 68, and HWS 46-3000. The substances differ in their silicone oil and PFA components, resulting in different specific gravities and viscosities of the products (Table 2).

Oxane HD (Bausch \& Lomb, Toulouse, France) is a mixture of silicone oil (Oxane 5700; Bausch \& Lomb) and a mixed fluorinated and hydrocarbonated olefin (RMN3). It has been used in several clinical series for the treatment of complicated RRD and recurrent macular hole. $^{20,27,32,35,49,50}$ The substance was removed on average after 2 months and complication rates seem to be significantly lower compared to F6H8 or other earlier tamponades. However, significant rates of emulsification and a rise in IOP could still be noticed. ${ }^{20,27}$ Oxane HD is the lightest of the three new tamponades - this might be one of the reasons why slightly higher redetachment rates could be noticed with this substance, when comparing the overall outcomes with other tamponades $^{21}$ (Table 1) as well as individual series with different tamponades conducted within the same institution. ${ }^{18,22,32}$ Especially in eyes with previous scleral buckling surgery, relatively light tamponades do not seem to enable an efficient tamponade in the area central to the indent. ${ }^{19,32}$

Densiron 68 (Fluoron Co, Neu-Ulm, Germany) is a solution of perfluorohexyloctane (F6H8) and $5000 \mathrm{cSt}$ silicone oil. ${ }^{51}$ The advantage of this solution is that it increases the viscosity of F6H8 from 2.5 to $1387 \mathrm{mPa}$, thereby reducing its tendency to disperse (the major reason for the clinical problems that were associated with the use of pure $\mathrm{F} 6 \mathrm{H} 8$ as a long-term tamponade). Densiron 68 has been investigated in several clinical series (Table 1), predominantly in patients with complicated RRD. ${ }^{21,24-26,52,53}$ Densiron 68 was removed after 2-3 months. It seems to be more stable and better tolerated than $\mathrm{F} 6 \mathrm{H} 8 .^{21,25,26}$ However, several reports reporting serious side effects or disappointing results have also been published. ${ }^{26,52}$ Densiron 68 has been chosen as the heavy tamponade of choice in the 'Heavy Silicone Oil Study' (HSO Study), the first multi-centre comparative trial of a heavy $v$ s conventional silicone oil tamponades. $^{54}$

HWS 46-3000 is the latest, heaviest and most viscous of the three new tamponades; a clinically significant emulsification could not be observed in the first clinical application of HWS 46-3000 when left in situ for 1-3 months and the initial report with low complication and high success rates are encouraging. ${ }^{22}$ However, the higher viscosity also increases the difficulties associated with the handling of the substance, for example, its removal. $^{22}$

\section{Indications}

Heavy tamponades have most commonly been used for complicated types of RRDs and redetachments (Table 1). This group of patients can further be divided into patients with PVR and without PVR. The majority of patients included into heavy tamponade studies were patients with postoperative PVR following previous vitrectomy or scleral buckling surgery. The percentage of patients with previous vitreoretinal surgery varies between none and $100 \%$, but it is more than $50 \%$ in the majority of studies (Table 1). Many series also include patients with previous blunt and penetrating eye trauma. ${ }^{6,12-14,20,25,32,34,48}$ This has to be kept in mind when 
evaluating the postoperative complications following heavy tamponades.

Patients with RRD not complicated by PVR mainly consist of those with breaks or tears in the lower fundus periphery. The largest subgroups are patients with giant tears $5,11,17,20,33,34$ or large, multiple, and posterior breaks. ${ }^{20-22,27,32,33}$ Another subgroup is myopic patients with RRD associated with a macular hole, a posterior staphyloma, or recurrent macular holes. ${ }^{11,12,21,26,34,35,50}$ Uncommon indications that were included into clinical trials as single cases only were tractional RD associated with diabetic retinopathy, ${ }^{6,11,14,15}$ retinoschisis, ${ }^{17}$ endophthalmitis, ${ }^{13,16,25}$ retinopathy of prematurity, ${ }^{13}$ choroidal detachment, ${ }^{32}$ branch retinal vein occlusion, ${ }^{14}$ hypotony, ${ }^{11}$ and retinal necrosis. ${ }^{6}$ Few patients with breaks in the superior periphery in addition to inferior pathology have been treated with heavy tamponades. ${ }^{11,21,26}$ The patient's inability to keep an appropriate posture postoperatively has also been a rationale behind the use of heavy tamponades in some patients with RRD. ${ }^{11,21}$

\section{Surgical techniques}

The method of tamponade injection may have an influence on the complication rate. ${ }^{55,56}$ In most series, an air-heavy tamponade exchange was the preferred method. ${ }^{11,21,22,32-35}$ If larger retinotomies are present, this might be complicated by slippage of the retinotomy edge; in such cases, a heavy liquid-heavy tamponade exchange can be performed, as an interface between the heavy liquid and the heavy tamponade becomes visible. ${ }^{57}$ Using Oxane HD, Wolf et al ${ }^{20}$ preferred this approach in the majority of cases. However, interactions between heavy liquids and heavy tamponades might lead to a 'contamination' of the heavy tamponade, thereby increasing the risk for emulsification, 'sticky' silicone oil, and an inflammatory response. ${ }^{27,55,56}$ Roider et $a l^{14}$ routinely used a Ringer solution-heavy tamponade exchange, using the 'heavy liquid' effect of the heavy tamponades. Although no study has compared the different methods of heavy tamponade injection, an air-heavy tamponade exchange seems to be the recommended technique at present. An additional filling of the anterior chamber in aphakic eyes has been performed by some authors using F6H8. ${ }^{11,14}$ However, due to the possible toxic effects on the corneal endothelium ${ }^{13,14,16}$ the risk for pupillary block glaucoma and the different properties of the recently developed heavy tamponades, this seems no longer advisable.

The need for additional scleral buckling in addition to heavy tamponades is a point of controversy. On the one hand, the elimination of additional scleral buckles is thought to be one of the major advantages of heavy tamponades. ${ }^{21}$ It facilitates and shortens the surgery and avoids typical complications associated with these explants, for example, changes in refraction, muscle imbalances, anterior segment ischaemia, extrusion, and infection. In addition, heavy tamponades seem to show a reduction of the tamponade effect around the indents. ${ }^{19}$ This could be of clinical significance, especially when 'lighter' heavy tamponades, such as Oxane HD, are used. $^{20,22,32}$ Further, heavy tamponades are often used when larger retinotomies are made. The retinotomy edges are usually located central to the indent where no supporting effect from the indent can be expected. The development of surgical techniques with macular translocation surgery and $360^{\circ}$ retinotomy has shown that no additional scleral buckling is needed in these situations. Finally, very high success rates have been achieved with heavy tamponades without additional scleral buckling, demonstrating the potential of this approach. ${ }^{21}$ On the other hand, some authors achieved excellent results with additional buckling. ${ }^{33}$ No definite recommendation can be given based on the currently available literature; however, it seems that an additional scleral buckle is not essential to achieve a successful outcome with heavy tamponades.

\section{Time to removal of tamponade}

The duration of the intraocular heavy tamponade is of critical importance regarding the success and complication rates associated with this type of surgery. On the one hand, a certain period of time is necessary to achieve sealing of patent breaks and retinotomy edges

Table 2 Physical and chemical properties of new heavy tamponades compared to F6H8

\begin{tabular}{|c|c|c|c|c|}
\hline & Densiron 68 & Oxane HD & HWS 46-3000 & $\mathrm{F} 6 \mathrm{H} 8$ \\
\hline Components (weight \%) & $\begin{array}{c}30.5 \% \mathrm{~F} 6 \mathrm{H} 8 \\
69.5 \% \mathrm{SiO} 5000\end{array}$ & $\begin{array}{c}11.9 \% \text { RMN3, } \\
88.1 \% \text { Oxane } 5700\end{array}$ & $\begin{array}{c}55 \% \mathrm{~F} 4 \mathrm{H} 5 \\
45 \% \mathrm{SiO} 100000\end{array}$ & NA \\
\hline Specific gravity $\left(\mathrm{g} / \mathrm{cm}^{3}\right)\left(25^{\circ} \mathrm{C}\right)$ & 1.06 & 1.02 & 1.118 & 1.35 \\
\hline Refractive index $\left(20^{\circ}\right)$ & 1.387 & 1.4 & 1.366 & 1.343 \\
\hline Interfacial tension $v s$ air $(\mathrm{mN} / \mathrm{m})$ & 19.13 & & 18.8 & 19.7 \\
\hline Interfacial tension $v$ s water $(\mathrm{mN} / \mathrm{m})$ & 40.82 & $>40$ & 41.3 & 45.3 \\
\hline Viscosity $(\mathrm{mPa})\left(25^{\circ}\right)$ & 1349 & 3800 & 2903 & 3.44 \\
\hline
\end{tabular}


before the tamponade can safely be removed. The duration of this critical time period differs from case to case but it is definitely longer the more complicated the morphology, for example, extended PVR reaction, retinotomies, etc. On the other hand, the amount of emulsification of heavy tamponades is, among other factors, also time dependent - the longer the time period since installation of the tamponade, the higher the rate of emulsification. This was a particular concern with the first heavy tamponades that were used, eg PFCL or PFA. These tamponades had a relative low viscosity and, therefore, a greater tendency to emulsify early, sometimes within days after its installation. ${ }^{13}$ The first heavy tamponades were, therefore, not well tolerated for longer periods of time. PFCL was removed within the first week, and this usually necessitates further long-term tamponades in the majority of patients. ${ }^{5,43}$

With increasing viscosity of the tamponade agents and more stable substances, a better tolerance can now be demonstrated. This is underlined by the longer times to removal, for example, a mean of 108 days or up to 4 months with Densiron $68,{ }^{21,25}$ a mean of 88 days and up to 4 months with Oxane $\mathrm{HD},{ }^{32,35}$ and up to 3 months with HWS 46-3000. ${ }^{22}$ There are few reports of patients with long-term heavy tamponades up to 400 days, usually in patients who denied its removal..$^{20,25}$ No apparent detrimental effect of Densiron 68 and Oxane HD has been described in these cases. In summary, there is no fixed time period in which the newer tamponades have to be removed and the time point of removal depends on the individual case, the retinal situation, and possible complications of the tamponade in situ. Most surgeons would recommend to remove the tamponade once '... the retina appears attached and stabilised without inflammation, laser photocoagulation is pigmented and retinotomies are scarred' ${ }^{22}$ The guidelines of the HSO Study advise to leave the tamponade in the eye for a minimum of 2 months and recommend its removal between 2 and 6 months. ${ }^{54}$

\section{Anatomical results}

There is a large variation in the anatomical and functional results of heavy tamponades and a comparison of the clinical studies published so far is problematical. The studies vary in all major variables with an influence on outcome, for example, tamponade agent, inclusion and exclusion criteria, surgical technique, and follow-up (Table 1). In addition, most studies include only a relatively small number of patients in a retrospective study design. Finally, the definition of anatomical success (with or without tamponade in situ, partial or complete reattachment) and functional success vary from study to study.
Overall, the primary success rates, most commonly defined as persistent retinal attachment following tamponade removal, vary between $33^{26}$ and $86 \%^{11}$ with the majority being around $70 \%$ (Table 1 ). In uncomplicated primary cases, the reported reattachment rates vary between 33 and $75 \% .^{18,26}$ The final success rates vary between $71^{13}$ and $100 \%,{ }^{17,22,34}$ with large differences in the percentage of patients with intraocular tamponades in situ at the last follow-up examination. Overall, retinal reattachment was achieved in about $90 \%$ of patients in the published series (Table 1).

One particular subtype of complicated RRD is myopic patients with posterior staphyloma or macular holes. In theory, these cases seem to be ideal candidates for heavy tamponades because a sufficient tamponade effect should be achieved with the patient in the upright or supine position. Indeed, very good results could be achieved in this subgroup of patients with Oxane HD. ${ }^{35}$ However, the patients underwent ILM peeling as well, which might have improved the success rates, and other authors found that redetachments can occur even with the heavy tamponade in situ, as described by Sandner et $a l^{26}$ in three out of four cases.

\section{Functional results}

Because of the differences in recording and displaying visual acuity results in addition to the variations described above, it is even more difficult to interpret the functional outcome of clinical studies of heavy tamponades published so far. All levels of visual acuity outcomes have been reported, ranging from no perception of light to logMAR 0.1 (Table 1). In summary, most patients seem to fall into the categories of severe low vision (logMAR 1.3-1.0) and moderate low vision (logMAR 0.9-0.6) at the last follow-up visit, which probably is to be expected against the background of the percentage of difficult situations of the included patients. However, it is noteworthy that the use of heavy tamponades does not exclude an excellent final visual outcome in selected cases, for example, cases with no major macular pathology preoperatively. Almost all series include cases with near-normal or normal vision ( $\log$ MAR better than 0.5 ) at the end of followup. ${ }^{6,12,15,16,18,21,22,32}$ Comparing pre- with postoperative visual acuity, most studies report an improvement in visual acuity in the majority of patients. When a statistical analysis of the change in visual acuity was performed, several studies have demonstrated a statistically significant improvement, ${ }^{21,22,25,26,35}$ while others have found no significant difference. ${ }^{11,13}$

For the reasons described above, a comparison of early heavy tamponades (PFCL, fluorosilicone, and F6H8) with the newer substances (Oxane HD, Densiron 68, and HWS 
46-3000) is not possible based on the studies available to date. However, the newer agents seem to achieve better anatomical and functional results, with primary reattachment rates of $81 \%$ and a mean logMAR of 0.9 with Densiron $68^{21}$ and $84 \%$ primary reattachment and a mean logMAR of 1.1 with HWS 46-3000. ${ }^{22}$

\section{Complications}

Serious and frequent complications have long been the major obstacle against the widespread use of heavy tamponades; indeed, some early publications reported considerable complication rates that did not support their use. ${ }^{13,14,42}$ Many of these severe complications can be associated with an early emulsification and foreign body reaction to the substances used in early series, for example, PFCL and F6H8 ${ }^{16,45}$ More recently developed heavy tamponades have a higher viscosity, seem to be biologically more stable, are better tolerated, can be left in the eye for a longer period of time, and are associated with fewer complications. ${ }^{21,22}$ However, significant problems have also been reported with the use of these newer substances. ${ }^{26,27,52}$

It is difficult and often impossible to distinguish between problems caused by the tamponade and those that are associated with the underlying complicated retinal disease. Emulsification, for example, is certainly related to the physical and chemical properties of the tamponade substance. However, whether emulsification causes an increased inflammatory response and membrane formation is not easy to establish. Unrelated to the tamponade used, high complication rates can be expected in complicated RRD cases, the major group of patients that has been studied in heavy tamponade trials. For example, an analysis of 555 eyes with complicated retinal detachments that were operated on with conventional tamponades showed redetachments in $43 \%$, a final success rate of $73 \%$, cataract progression in $92 \%$, corneal oedema in $7 \%$, an elevated IOP in $2 \%$, and hypotony in $15 \% .{ }^{58}$ Severe reproliferations, the major reason for an anatomical and functional failure, can be seen with or without the use of heavy tamponades and with or without emulsification. Finally, the complication rate is also related to the case selection of the individual series, the overall quality of the surgery, the period of time that the tamponade has been left in the eye, the methodology of identifying the complications, and the follow-up period. The majority of recently published case series differs in one or more of these aspects. This leaves a comparison to conventional tamponades problematical. Only a comparative trial will be able to address this problem in a suitable way. ${ }^{54}$

\section{Corneal complications}

Corneal damage has been associated with some heavy tamponades in a small number of published series, mainly associated with F6H8. Gerding and Kolck ${ }^{13}$ found corneal stromal and epithelial oedema following F6H8 use in 6/17 cases (35\%), and persistent problems in 4/17 (24\%) (some of these with previously diseased cornea, for example, previous corneal transplant or penetrating injury). Roider et $a l^{14}$ reported two out of five cases with corneal opacities, Vote et $a l^{16}$ describe one out of a series of five cases. In contrast to the presumed endothelial damage, Schatz et $a l^{15}$ found a relatively high incidence of corneal epithelial pathologies in 6/18 patients (33\%), but it is unclear whether this is related to the tamponade agent or other aspects of the surgical technique. In contrast, Kirchhof et $a l^{11}$ found no corneal changes in a multi-centre trial, despite direct F6H8 to cornea contact in 11 cases; endothelial cell counts were performed in four cases and showed no decrease following F6H8 tamponade. Corneal changes have specifically been looked for in recent series of heavy silicone oils. ${ }^{21}$ So far, no reports of possible corneal toxicity of Oxane HD, Densiron 68, or HWS 46-3000 have been published. Sandner $e a^{26}$ reported one case of a corneal graft failure following vitrectomy with Densiron 68; again, the causative relationship to the heavy tamponade cannot be determined with certainty.

In summary, it seems that no major corneal complications are to be expected with the 'new generation' heavy silicone oils. The reported corneal problems have mostly been associated with the use of F6H8, which is no longer used as a heavy tamponade in its purified form. In addition, a significant number of these patients experienced an intentional or unintentional tamponade movement into the anterior chamber with direct corneal endothelial contact. Because of the advances of anterior segment surgery and the increased viscosity of new heavy oils, this can nowadays only rarely be seen. At present, corneal problems cannot be considered a typical complication associated with the intraocular use of heavy tamponades.

\section{Cataract development}

Cataract development is a known complication of any type of pars plana vitrectomy. The main factors that influence the rate and dynamics of cataract development are the grade of lens opacities at the time of surgery, any type of lens touch that might occur during surgery, the age of the patient, and the tamponade used.

Conventional silicone oil has a higher tendency to cause cataract than gas tamponades and balanced salt solution. ${ }^{59}$ Although no comparative data are available, 
heavy tamponades seem to cause cataract progression, nuclear and posterior subcapsular, ${ }^{24}$ in a relatively high percentage of patients that seems comparable to conventional silicone oil. In addition, there seems to be a relatively rapid opacification of the posterior capsule in pseudophakic eyes. ${ }^{12}$ This could be the result of an increased cellular infiltration, possibly triggered by a foreign body reaction to emulsified tamponade. ${ }^{16,45}$ Cataract progression has been documented in a high percentage of patients with all types of heavy tamponades.

Using F6H8, Kirchhof et $_{\text {al }}{ }^{11}$ noted cataract progression in a series with a relatively short follow-up in 90\% (9/10) of phakic patients. They describe a feathery posterior subcapsular opacification in some patients but more commonly an increase in nuclear sclerosis, findings comparable to those following Densiron 68 described by Lappas et al. ${ }^{24}$ In a multi-centre trial of Densiron 68, all phakic patients developed some type of cataract progression during follow-up. ${ }^{21}$ Progressive lens changes could also be seen following Oxane HD in $38 \%$ of patients. $^{32}$ HWS 46-3000 was associated with cataract progression in all phakic patients. ${ }^{22}$

In summary, a significant cataract progression is to be expected in almost all phakic patients treated with vitrectomy and heavy tamponades. In addition, a significant posterior capsular fibrosis usually occurs in pseudophakic patients. No data are available to determine whether cataract surgery should be combined with the initial procedure, with the tamponade removal, or at a later stage. In our department, we currently would leave the crystalline lens in situ during the initial surgery if possible. We then usually combine the removal of the heavy tamponade with cataract surgery and a surgical posterior capsulotomy.

\section{Elevation of IOP}

\section{Acute rise in IOP}

Acute pupillary block type of elevations of the IOP has been noted with various heavy tamponades. One series describes two cases of presumed pupillary block due to a forward bulging of the inferior iris with a F6H8. ${ }^{11}$ The authors aimed at an almost complete fill in aphakic eyes, which might explain these acute IOP spikes secondary to a pupillary block. However, a pupillary block was also seen in a pseudophakic patient. ${ }^{11}$ Hoerauf et al ${ }^{17}$ described a pupillary block caused by $\mathrm{O} 62$ heavy tamponade bubbles that were trapped between an intraocular lens and the iris, thereby narrowing the chamber angle. An unplanned displacement of the heavy tamponade could be seen in several cases, including phakic patients, with $\mathrm{F} 6 \mathrm{H} 8$ and Oxane HD; ${ }^{13,27}$ however, a rise in IOP was seen in two cases following F6H8 tamponade. ${ }^{12,32}$ Tognetto et al ${ }^{34}$ reported three cases of IOP rise caused by an overfilling with a mixture of F6H8 and silicone oil. In all cases with overfilling or displacement of the tamponade into the anterior chamber, the IOP returned into the normal range following partial removal of the tamponade. One thing to remember is to perform a peripheral iridectomy at the 12 o'clock position in contrast to the usual 6 o'clock with conventional tamponades in aphakic patients.

\section{Chronic rise in IOP}

A prolonged rise in the IOP can be caused by increased intraocular inflammation, emulsification of the tamponade with consecutive blockage of the aqueous outflow, a steroid response to the topical antiinflammatory therapy, or possibly biological reactions to the tamponade. Such a rise in IOP has been seen in clinical series of all heavy tamponades, especially with the first generation of heavy tamponades. ${ }^{5}$ In the vast majority, these can be controlled medically and do not cause a long-term damage. If the rise in IOP is associated with tamponade emulsification, the removal of the tamponade usually leads to a reduction in the IOP. However, several cases necessitating IOP-lowering surgery have been reported. ${ }^{25}$ It also has to be kept in mind that an increase in IOP can be seen in a significant number of patients with complicated retinal detachments irrespective of the tamponade agent. ${ }^{58}$

With F6H8, no significant increase in IOP could be seen in two larger series. ${ }^{11,13}$ A mixture of silicone oil and F6H8 was associated with an IOP rise in $31-39 \% .{ }^{18,33,34}$

In larger series with a longer follow-up after Oxane $\mathrm{HD}$, a rise in IOP could be seen in 14-18\%. ${ }^{20,32}$ Short-term elevations in IOP were reported by Cheung et $\mathrm{al}^{35}$ in $42 \%$; in another series, no significant IOP rise was noted following Oxane HD application. ${ }^{27}$ With HWS 46-3000, only 1 out of 32 patients was noted to have an elevated IOP. $^{22}$ A higher rate of rise in IOP could be noted with Densiron 68 in 8-19\%. ${ }^{21,25,26}$ Sandner and Engelmann ${ }^{25}$ recommend flushing of the anterior chamber and chamber angle when Densiron 68 is removed in all cases.

In summary, moderate levels of elevated IOPs can be seen following heavy tamponades. In most cases, these can be controlled with medical therapy and do not cause greater concern. However, a monitoring of the IOP should be part of the routine postoperative management of patients; in cases of an elevated IOP, the removal of the tamponade should be considered.

\section{Ocular hypotension}

Ocular hypotension is one of the most feared complications of complicated RRD; with conventional 
tamponades, it can be seen in around $15 \%$ of eyes and is usually caused by persistent retinal detachment, recurrent PVR, and membrane formation over the ciliary body. ${ }^{58}$ Apart from the inescapable proportion of patients with hypotony following complicated RRD, an additional contribution to this problem caused by a biological reaction to heavy tamponades, for example, F6H8, has been postulated..$^{13}$ It was thought that a foreign body reaction to heavy tamponades triggers an increased inflammatory response, leading to an increased membrane formation with the consequences of redetachment, recurrent PVR, and cyclitic membranes. In fact, such changes can be seen following unsuccessful surgery with conventional silicone oil, ${ }^{60}$ and similar changes are likely to occur with heavy silicone oil. Whether or not the heavy tamponade part of the recently developed heavy silicone oils adds an additional immunogenic factor is unknown at present. However, the combination of the new heavy silicone oils and advances in the surgical technique seem to have led to a lower rate of hypotony over the past years. With F6H8, Gerding and Kolck $^{13}$ could see a high rate of hypotony of $81 \%$ in their series of 16 patients. Where mentioned, hypotony rates of other series with the same tamponade were 7 and $11 \% .{ }^{12,15}$ Mixtures of conventional silicone oil and $\mathrm{F} 6 \mathrm{H} 8$ also did not show increased hypotony rates. ${ }^{18,33,34}$ With Densiron 68, Oxane HD and HWS 463000 , the reported hypotony rates are between none and $8 \%$ and do not seem to exceed the rate of this complication that would be expected with conventional surgery. ${ }^{12,20,21,25,32}$ With the exception of the series of Gerding and Kolck, ${ }^{13}$ it can therefore be summarised that there is no indication for an increased risk of postoperative hypotony with heavy tamponades compared to conventional tamponades.

\section{Intraocular inflammation}

\section{Anterior chamber inflammation}

Some of the early clinical reports of heavy tamponades reported relatively high rates of intraocular inflammations, including fibrin and retro-pupillary membrane formation..$^{5,13,14,16}$ The use of 062 as an intraocular tamponade had to be discontinued because an anterior chamber inflammation occurred in all 11 cases in the pilot series of Hoerauf et al. ${ }^{17}$ It was therefore postulated that heavy tamponades, in particular F6H8, modify and amplify the wound healing response that is already present in complicated RRD cases. ${ }^{13}$ However, subsequent series of $\mathrm{F} 6 \mathrm{H} 8$ or combined $\mathrm{F} 6 \mathrm{H} 8$ and silicone oil showed significant lower rates of intraocular inflammation compared to the series published by Gerding et al. ${ }^{11,12,34}$ Following application of Oxane HD,
Theelen et $a l^{27}$ noticed keratic precipitates in 37\% (7/19) of patients. The accompanying anterior chamber inflammation did not resolve with topical steroid therapy and resemble the clinical picture of granulomatous uveitis. However, other authors have found only little ${ }^{20}$ or no ${ }^{32}$ particular anterior chamber reaction with Oxane HD. With Densiron 68, Wong et $a l^{21}$ noticed a moderate anterior chamber inflammation in $8 \%(3 / 42)$ at 1 week following the tamponade. Sandner and Engelmann ${ }^{25}$ report mild to moderate anterior chamber reactions in $21 \%$ (10/48); however, intraocular fibrin was noted in six of these cases and two further cases developed a sterile hypopyon secondary to a severe intraocular inflammatory reaction. All cases could be controlled with topical anti-inflammatory therapy. Majid et $a l^{52}$ reported single cases of fibrinous uveitis associated with Densiron 68. No patients with intraocular inflammations were seen following application of a HSS 46-3000 tamponade. ${ }^{22}$

\section{Posterior chamber inflammation}

Different levels of posterior chamber inflammation have been noticed with heavy tamponades. The factors that might influence the rate of posterior chamber inflammation are an emulsification of the heavy tamponade, resulting in a foreign body-type inflammatory reaction; ${ }^{45}$ a 'contamination' of the tamponade with heavy liquids used during intraoperative manipulations; ${ }^{27}$ and vigourous physical activity with the tamponade in situ. ${ }^{16}$ Kirchhof et al ${ }^{11}$ noticed pigmented clumps on the back of the crystalline or intraocular lens in $17 \%(4 / 23)$ following the use of F6H8. Hiscott et al ${ }^{45}$ performed histology examinations of epiretinal membranes following F6H8 tamponades. They found a picture similar to membranes seen following conventional silicone oil tamponades. However, a greater foreign body reaction, indicated by a higher rate of multinucleated giant cells and macrophages, could be seen. The reason for this could be the greater tendency to emulsify as a consequence of the relatively low viscosity of F6H8. Roider et $a l^{14}$ noticed 'fluffy material' on the anterior surface of the tamponade on its removal in 2/5 patients. Vote $e t a l^{16}$ described one case with a 'pea soup vitreous' following vigourous physical activity; the inflammation quickly resolved following removal of tamponade. Following application of O62, Hoerauf et $a l^{17}$ saw whitish precipitates on the posterior lens surface in all 11 cases. With Oxane HD, Theelen et al ${ }^{27}$ observed one case of a granulomatous uveitis and suspected an immune reaction to the heavy tamponade. No uncommon posterior chamber inflammations have been reported in other series of Oxane HD or following Densiron 68 or HWS 46-3000 application. ${ }^{20-22,26,32,61}$ 


\section{Dispersion/emulsification}

The terms emulsification and dispersion are used to describe a clinically visible separation of small droplets from the ideally single large bubble of an intraocular tamponade. This phenomenon is a well-known complication of conventional silicone oil tamponades and is one of the major reason for the necessity to remove the tamponades. Emulsification has been documented following installation of all types of heavy tamponades in varying degrees. In contrast to conventional oil, it has been seen earlier and more pronounced with the early heavy tamponades, depending on the substance used. The description of emulsification varies from series to series and sometimes it is subdivided into emulsification visible on clinical examination or during tamponade removal.

Emulsification and dispersion might or might not be of clinical significance. The undesired effects are

(1) decreasing tamponade effect secondary to a smaller sized tamponade bubble; (2) initiation or amplification of an intraocular inflammatory and foreign body response, possibly leading to the formation of fibrin, pigmented or whitish precipitates or epiretinal PVR membranes;

(3) mechanical blockage of aqueous outflow or inflammation within the trabecular meshwork. These pathways can result in a rise in IOP; (4) visually disturbing droplets attached to the lens, capsular bag, or intraocular lens surface; and (5) difficulties in removing sticky droplets (see below) or remnants in awkward positions (for example, from the posterior lens capsule or in the anterior chamber in phakic eyes).

An emulsification of F6H8 could be noted as early as 3 days after its installation. Overall, dispersion occurred in $52 \%(12 / 23)$ in the series published by Kirchhof et al. ${ }^{11}$ During removal of the tamponade, the authors estimated that about $90 \%$ of the substance formed one bubble with the remaining $10 \%$ dispersed into small bubbles. Gerding and Kolck $^{13}$ has seen an emulsification of F6H8 in 17 out of 17 patients on tamponade removal and in 11/17 clinically (59\%), some as early as day 1 after installation. The use of a F6H8-silicone oil mixture led to visible emulsification in only 1 out of 26 cases. ${ }^{34}$ With O62, severe emulsification occurred in $100 \%(11 / 11)$ of cases, starting at 2 weeks postoperatively; in one case the bubbles were extremely difficult to remove, as they were caught between the iris and the lens. ${ }^{17}$ No emulsification was reported in four cases that were treated with OL62HV. ${ }^{14}$ With Oxane HD, Rizzo et al ${ }^{18}$ and Wolf et $a l^{20}$ could not notice an emulsification with the tamponade in situ; interestingly, emulsification occurred in five patients with a conventional silicone oil tamponade following the removal of Oxane HD. Other groups noticed an emulsification in $8 \%(1 / 12)$ and $11 \%(2 / 19)$, visible droplets were noticed on removal in all patients reported by Theelen et al. ${ }^{27,35}$ With Densiron 68 , dispersion occurred in $16 \%(6 / 42)$ and $15 \%(7 / 48))^{21,25}$ Only one of the cases described by Sandner and Engelmann ${ }^{25}$ had increased IOP; nevertheless, the authors recommend anterior chamber washout in all patients at the time of Densiron 68 removal. In contrast to these groups, Majid et $a l^{52}$ saw clinically emulsification in 8 cases out of a total of $40(20 \%)$. Some of these cases were associated with significant clinical problems (eg uveitis or epiretinal membrane formation), others did not seem to be of clinical relevance. No emulsification could be seen with the new tamponade HWS 46-3000. ${ }^{22}$

\section{Redetachment and PVR}

Preoperatively, a complete retinal reattachment could be achieved in almost all reported cases with heavy tamponades. In very few cases, this was not accomplished. ${ }^{25}$

As with conventional silicone oil tamponades, postoperative retinal redetachments can occur with a heavy tamponade in situ or after its removal. ${ }^{13,21,32-34}$ In contrast to conventional silicone oil, redetachments with a heavy tamponade in situ usually affect the superior periphery. ${ }^{13,17,21,32}$ Only Sandner and Engelmann ${ }^{25}$ found that the majority of redetachments occurred in the lower fundus periphery. With the tamponade in situ, redetachments can occur early in the postoperative course $^{13}$ or several months after the installation of heavy tamponades. ${ }^{20}$ Interestingly, Wolf et $a l^{20}$ also observed three cases with superior redetachments that resolved spontaneously over time with the heavy tamponade in situ.

Few cases with redetachments of the inferior retina with heavy tamponades in situ have been noticed. ${ }^{13,17,20,32}$ In the vast majority of cases, the inferior retina and the posterior pole remain attached with a heavy tamponade in situ. One of the potential advantages of heavy tamponades might be that, compared to conventional oil, a lower rate of macula-off redetachments occurs, ${ }^{21,53}$ although macula-off detachments have also been described with a heavy tamponade in situ. ${ }^{32}$ Most authors think that redetachments following heavy tamponades are easier to treat because they mostly involve the superior retinal quadrants and are more accessible to intraocular gas tamponades than redetachments of the lower periphery following conventional silicone oil tamponade.

The redetachments seen with heavy tamponades in situ in the superior periphery were mainly caused by PVR rather than new breaks or insufficient tamponade of pre-existing breaks. ${ }^{13,17,21,32}$ Epiretinal membrane formation with an attached retina could also be 
observed. ${ }^{16}$ Histology examination of PVR membranes following F6H8 tamponade demonstrated a pathology similar to other PVR-type membranes but with multinuclear giant cells and macrophages. ${ }^{16,45}$ A foreign body reaction to emulsified $\mathrm{F} 6 \mathrm{H} 8$ could be the explanation for these findings. Majid et $a l^{52}$ also noticed increased membrane formation in association with emulsification of the heavy tamponade as well as associated cystoid macular oedema. Although it is difficult to judge whether postoperative PVR formation is increased by the heavy tamponade or resembles a complication that is related to the disease, it seems that some of the earlier used heavy tamponades initiated a membranous would-healing response. ${ }^{14}$

In contrast to redetachments following primary vitrectomy with gas tamponade, new retinal breaks are an infrequent cause of redetachments following heavy tamponades. Sandner and Engelmann ${ }^{25}$ found that only one in eight redetachments of the superior retina was caused by a new retinal break. Rizzo et $a l^{32}$ describe contraction of residual vitreous cortex as a potential mechanism resulting in redetachments. In contrast to this finding, most redetachments in the lower periphery were caused by newly developed breaks with Densiron 68 in situ, ${ }^{25}$ although PVR redetachments of the lower periphery have also been described. ${ }^{13,32}$ Rizzo and colleagues ${ }^{18,22,32,33}$ found varying pathologies of retinal redetachments in their series with different heavy tamponades. They observed that more pathological changes and more new breaks in the inferior retina can be seen following the use of Oxane HD and speculate that this tamponade might be too light and provides a suboptimal tamponade effect, especially in the case of additional scleral buckling. ${ }^{32}$ As with conventional silicone oil tamponades, retinal redetachments can occur after removal of the tamponade; overall, this seems to be slightly more common than redetachments with the tamponade in situ. ${ }^{13,21,25,32}$

\section{Uncommon complications and subretinal tamponade remnants}

Uncommon complications that were reported in clinical series with an unclear association to heavy tamponades were one case of ischaemic optic neuropathy, ${ }^{25}$ one case of central retinal artery occlusion 4 weeks following Oxane HD removal, ${ }^{20}$ and two cases of scattered retinal haemorrhages following Oxane HD. ${ }^{20}$ Severe complications have been reported following the use of OL62HV. Four out of four patients developed severe PVR reactions, two out of four patients had a clinical appearance similar to retinal necrosis, and one eye developed optic atrophy with no perception of light within 4 weeks. $^{14}$

\section{Sticky silicone oil and subretinal tamponade}

There are anecdotal reports of sticky silicone oil associated with heavy tamponades, although this is a complication that is often discussed as a potential complication of heavy tamponades. Recent publications of the second-generation heavy tamponades Oxane HD, Densiron 68, and HWS 46-3000 reported no cases of sticky silicone oil. ${ }^{20-22}$ Problems can arise if a high number of emulsified droplets exist on removal of the tamponade; depending on the type of tamponade, these can be adherent to intraocular structures, for example, get trapped between the lens and the iris, which makes their removal sometimes difficult. If residual droplets affect the visual axis, this might significantly affect the patient's vision. ${ }^{17}$ Subretinal remnants following removal of F6H8 was noted in 4/23 (17\%) in one series ${ }^{11}$ and in single cases in two other series of F6H8 and O62. ${ }^{13,16,17}$ This is likely to be due to the behaviour of these particular tamponades, which is comparable to PFCL. The subretinal remnants usually cause a retinal atrophy in the area of the residual bubble but mostly do not cause further problems. No such complications have been noted with Densiron 68, Oxane HD, or HWS 46-3000. ${ }^{20,22}$

\section{Summary and conclusion}

Heavy tamponades were developed as a postoperative tool for the treatment of complicated RRD of the lower fundus periphery. This group of substances underwent a substantial evolution over the past years. Early heavy tamponades, for example, fluorosilicone, C10F18, and F6H8, were associated with relatively high complication rates, especially emulsification and severe inflammatory reactions. Because of these complications, the early heavy tamponades could not be left in the eye for a long period. Combinations of $\mathrm{F} 6 \mathrm{H} 8$ and conventional silicone oil were better tolerated than $\mathrm{F} 6 \mathrm{H} 8$ alone but achieve a lesser tamponade effect. Other tamponades that showed promising results in vitro, for example, O62 and OL62HV, led to severe postoperative problems and were discontinued.

Following the initial disappointment, the new generation of heavy silicone oils (Oxane HD, Densiron 68, and HWS 46-3000) shows promising results in the initial clinical trials. All three substances seem to be more stable and are less frequently associated with emulsification and intraocular inflammation than earlier tamponades. Initial clinical studies have shown that their tolerability is comparable to conventional silicone oil and vitreoretinal surgeons now seem to have a tool in their hands that facilitates the treatment of complicated RRD in the inferior fundus periphery without the drawbacks of increased emulsification, inflammation, and shorter 
tamponade duration. But while some authors have achieved satisfactory results in a complicated subset of patients, ${ }^{21,22}$ other authors report only modest results that show now obvious advantage over conventional tamponades. ${ }^{20,25,26}$ With heavy tamponades, the mixture of aqueous and proliferative stimuli can be displaced away from the inferior retina - but it cannot be removed completely. The location of new problems is shifted from the inferior to the superior retina, but not lessened in a way that would substantially alter the natural history of PVR.

It seems that heavy silicone oil is a useful tool in selected patients but not the magic bullet against PVR or a guarantee for good results in every complicated RRD. The better reattachment of the lower periphery and especially the higher rate of macula-on situations seem to be arguments in favour of these new substances.

However, the precise role of heavy tamponades in the armamentarium of vitreoretinal surgeons is not clear at present. The operating technique (for example, the role of additional scleral buckling) is still a matter of debate as is the whole concept of how to treat inferior retinal detachments. Very good results have also recently been published with conventional silicone oil as a primary tamponade as well as a different method that uses only an air tamponade or avoids internal tamponades completely. ${ }^{36,62}$ Currently, a multi-centre randomised trial is on its way comparing heavy silicone oil with conventional silicone oil in complicated RRD surgery. ${ }^{54}$ It is to be hoped that the results of this trial will enable us to better define the current role of the next generation of heavy tamponades.

\section{References}

1 Bhisitkul RB, Gonzalez VH. 'Heavy oil' for intraocular tamponade in retinal detachment surgery. $\mathrm{Br}$ J Ophthalmol 2005; 89(6): 649-650.

2 Heimann K. Editorial. Graefe's Arch Clin Exp Ophthalmol 1993; 231: 613-614.

3 Scott JD. Fluorosilicone oil for retinal detachment. Br J Ophthalmol 1990; 74(11): 641-642.

4 Bottoni F, Bailo G, Arpa P, Prussiani A, Monticelli M, de Molfetta V. Management of giant retinal tears using perfluorodecalin as a postoperative short-term vitreoretinal tamponade: a long-term follow-up study. Ophthalmic Surg 1994; 25(6): 365-373.

5 Bottoni F, Sborgia M, Arpa P, De Casa N, Bertazzi E, Monticelli $\mathrm{M}$ et al. Perfluorocarbon liquids as postoperative short-term vitreous substitutes in complicated retinal detachment. Graefes Arch Clin Exp Ophthalmol 1993; 231(11): 619-628.

6 Gremillion Jr CM, Peyman GA, Liu KR, Naguib KS. Fluorosilicone oil in the treatment of retinal detachment. Br J Ophthalmol 1990; 74(11): 643-646.

7 Kertes PJ, Wafapoor H, Peyman GA, Calixto Jr N, Thompson $\mathrm{H}$. The management of giant retinal tears using perfluoroperhydrophenanthrene. A multicenter case series. Vitreon Collaborative Study Group. Ophthalmology 1997; 104(7): 1159-1165.

8 Peyman GA, Smith RT, Charles H. Injection of fluorosilicone oil and pars plana vitrectomy for complex retinal detachment. Can J Ophthalmol 1987; 22(5): 276-278.

9 Batman C, Cekic O. Effects of the long-term use of perfluoroperhydrophenanthrene on the retina. Ophthalmic Surg Lasers 1998; 29(2): 144-146.

10 Viebahn M, Buettner H. Perfluorophenanthrene unsuitable for postoperative retinal tamponade. Am J Ophthalmol 1994; 118(1): 124-126.

11 Kirchhof B, Wong D, Van Meurs J, Hilgers RD, Macek M, Lois $\mathrm{N}$ et al. Use of perfluorohexyloctane as a long-term internal tamponade agent in complicated retinal detachment surgery. Am J Ophthalmol 2002; 133(1): 95-101.

12 Stefaniotou MI, Aspiotis MV, Kitsos GD, Kalogeropoulos CD, Asproudis IC, Psilas KG. Our experience with perfluorohexyloctane (F6H8) as a temporary endotamponade in vitreoretinal surgery. Eur J Ophthalmol 2002; 12(6): 518-522.

13 Gerding H, Kolck A. [Perfluorohexyloctane as internal tamponade in patients with complicated retinal detachment. Results after 6 months]. Ophthalmologe 2004; 101(3): 255-262.

14 Roider J, Hoerauf H, Kobuch K, Gabel VP. Clinical findings on the use of long-term heavy tamponades (semifluorinated alkanes and their oligomers) in complicated retinal detachment surgery. Graefes Arch Clin Exp Ophthalmol 2002; 240(12): 965-971.

15 Schatz B, El-Shabrawi Y, Haas A, Langmann G. Adverse side effects with perfluorohexyloctane as a long-term tamponade agent in complicated vitreoretinal surgery. Retina 2004; 24(4): 567-573.

16 Vote B, Wheen L, Cluroe A, Teoh H, McGeorge A. Further evidence for proinflammatory nature of perfluorohexyloctane in the eye. Clin Experiment Ophthalmol 2003; 31(5): 408-414.

17 Hoerauf H, Roider J, Kobuch K, Laqua H. Perfluorohexylethan (O62) as ocular endotamponade in complex vitreoretinal surgery. Retina 2005; 25(4): 479-488.

18 Rizzo S, Genovesi-Ebert F, Belting C. The combined use of perfluorohexyloctane (F6H8) and silicone oil as an intraocular tamponade in the treatment of severe retinal detachment. Graefes Arch Clin Exp Ophthalmol 2006; 244(6) 709-716.

19 Wetterqvist C, Wong D, Williams R, Stappler T, Herbert E, Freeburn S. Tamponade efficiency of perfluorohexyloctane and silicone oil solutions in a model eye chamber. $\mathrm{Br} \mathrm{J}$ Ophthalmol 2004; 88(5): 692-696.

20 Wolf S, Schon V, Meier P, Wiedemann P. Silicone oil-RMN3 mixture ('heavy silicone oil') as internal tamponade for complicated retinal detachment. Retina 2003; 23(3): 335-342.

21 Wong D, Van Meurs JC, Stappler T, Groenewald C, Pearce IA, McGalliard JN et al. A pilot study on the use of a perfluorohexyloctane/silicone oil solution as a heavier than water internal tamponade agent. Br J Ophthalmol 2005; 89(6): 662-665.

22 Rizzo S, Genovesi-Ebert F, Vento A, Cresti F, Di Bartolo E, Belting C. A new heavy silicone oil (HWS 46-3000) used as a prolonged internal tamponade agent in complicated vitreoretinal surgery: a pilot study. Retina 2007; 27(5): 613-620. 
23 Herbrig E, Sandner D, Engelmann K. Anatomical and functional results of endotamponade with heavy silicone oil-Densiron 68 - in complicated retinal detachment. Ophthalmic Res 2007; 39(4): 198-206.

24 Lappas A, Kirchhof B, Konen W. [Effects of the long-term tamponade with Densiron on the lens]. Klin Monatsbl Augenheilkd 2007; 224(5): 434-437.

25 Sandner D, Engelmann K. First experiences with highdensity silicone oil (Densiron) as an intraocular tamponade in complex retinal detachment. Graefes Arch Clin Exp Ophthalmol 2006; 244(5): 609-619.

26 Sandner D, Herbrig E, Engelmann K. High-density silicone oil (Densiron) as a primary intraocular tamponade: 12month follow up. Graefes Arch Clin Exp Ophthalmol 2007; 245(8): 1097-1105.

27 Theelen T, Tilanus MA, Klevering BJ. Intraocular inflammation following endotamponade with high-density silicone oil. Graefes Arch Clin Exp Ophthalmol 2004; 242(7): 617-620.

28 Mackiewicz J, Muhling B, Hiebl W, Meinert H, Maaijwee K, Kociok $\mathrm{N}$ et al. In vivo retinal tolerance of various heavy silicone oils. Invest Ophthalmol Vis Sci 2007; 48(4): 1873-1883.

29 Soman N, Banerjee R. Artificial vitreous replacements. Biomed Mater Eng 2003; 13(1): 59-74.

30 Wong D, Lois N. Perfluorocarbons and semifluorinated alkanes. Semin Ophthalmol 2000; 15(1): 25-35.

31 Fawcett IM, Williams RL, Wong D. Contact angles of substances used for internal tamponade in retinal detachment surgery. Graefes Arch Clin Exp Ophthalmol 1994; 232(7): 438-444.

32 Rizzo S, Genovesi-Ebert F, Belting C, Vento A, Cresti F. A pilot study on the use of silicone oil-RMN3 as heavierthan-water endotamponade agent. Graefes Arch Clin Exp Ophthalmol 2005; 243(11): 1153-1157.

33 Rizzo S, Genovesi-Ebert F, Belting C, Foltran F, Gandolfo E, Lesnoni $\mathrm{G}$ et al. Long-term vitreous replacement with perfluorohexyloctane and silicone oil: preliminary reports of a multicentric study. Ophthalmologica 2005; 219(3): 147-153.

34 Tognetto D, Minutola D, Sanguinetti G, Ravalico G. Anatomical and functional outcomes after heavy silicone oil tamponade in vitreoretinal surgery for complicated retinal detachment: a pilot study. Ophthalmology 2005; 112(9): 1574.

35 Cheung BT, Lai TY, Yuen CY, Lai WW, Tsang CW, Lam DS Results of high-density silicone oil as a tamponade agent in macular hole retinal detachment in patients with high myopia. Br J Ophthalmol 2007; 91(6): 719-721.

36 Alexander P, Prasad R, Ang A, Poulson AV, Scott JD, Snead MP. Prevention and control of proliferative vitreoretinopathy: primary retinal detachment surgery using silicone oil as a planned two-stage procedure in high-risk cases. Eye, 2 February 2007; [e-pub ahead of print].

37 Joeres S, Kirchhof B, Joussen AM. PVR as a complication of rhegmatogeneous retinal detachment: a solved problem? Br J Ophthalmol 2006; 90(6): 796-797.

38 Wiedemann P, Leinung C, Hilgers RD, Heimann K. Daunomycin and silicone oil for the treatment of proliferative vitreoretinopathy. Graefes Arch Clin Exp Ophthalmol 1991; 229(2): 150-152.

39 Asaria RH, Kon CH, Bunce C, Charteris DG, Wong D, Khaw PT et al. Adjuvant 5-fluorouracil and heparin prevents proliferative vitreoretinopathy: results from a randomized, double-blind, controlled clinical trial. Ophthalmology 2001; 108(7): 1179-1183.
40 Chang S, Ozmert E, Zimmerman NJ. Intraoperative perfluorocarbon liquids in the management of proliferative vitreoretinopathy. Am J Ophthalmol 1988; 106(6): 668-674.

41 Peyman GA, Smith RT. Use of fluorosilicone to unfold a giant retinal tear. Int Ophthalmol 1987; 10(3): 149-151.

42 Eckardt C, Nicolai U. [Clinical and histologic findings after several weeks of intraocular tamponade with perfluorodecalin]. Ophthalmologe 1993; 90(5): 443-447.

43 Sirimaharaj M, Balachandran C, Chan WC, Hunyor AP, Chang AA, Gregory-Roberts J et al. Vitrectomy with short term postoperative tamponade using perfluorocarbon liquid for giant retinal tears. Br J Ophthalmol 2005; 89(9): 1176-1179.

44 Meinert H, Roy T. Semifluorinated alkanes - a new class of compounds with outstanding properties for use in ophthalmology. Eur J Ophthalmol 2000; 10(3): 189-197.

45 Hiscott P, Magee RM, Colthurst M, Lois N, Wong D. Clinicopathological correlation of epiretinal membranes and posterior lens opacification following perfluorohexyloctane tamponade. Br J Ophthalmol 2001; 85(2): 179-183.

46 Herbert E, Stappler T, Wetterqvist C, Williams R, Wong D. Tamponade properties of double-filling with perfluorohexyloctane and silicone oil in a model eye chamber. Graefes Arch Clin Exp Ophthalmol 2004; 242(3): 250-254.

47 De Molfetta V, Bottoni F, Arpa P, Vinciguerra P, Zenoni S. The effect of simultaneous internal tamponade on fluid compartmentalization and its relationship to cell proliferation. Retina 1992; 12(3 Suppl): S40-S45.

48 Bottoni F, Arpa P, Vinciguerra P, Zenoni S, De Molfetta V. Combined silicone and fluorosilicone oil tamponade (double filling) in the management of complicated retinal detachment. Ophthalmologica 1992; 204(2): 77-81.

49 Pagot-Mathis V, Benouaich X, Mathis A, Rico-Lattes I, Dumoulin A. [Management of complicated retinal detachment using a heavy silicon oil as temporary tamponade]. J Fr Ophtalmol 2006; 29(2): 137-145.

50 Rizzo S, Belting C, Genovesi-Ebert F, Cresti F, Vento A, Martini R. Successful treatment of persistent macular holes using 'heavy silicone oil' as intraocular tamponade. Retina 2006; 26(8): 905-908.

51 Kim YK, Gunther B, Meinert H. A new, heavier-than-water silicone oil: a solution of perfluorohexyloctane in polydimethylsiloxane. Eur J Ophthalmol 2005; 15(5): 627-637.

52 Majid MA, Hussin HM, Biswas S, Haynes RJ, Mayer EJ, Dick AD. Emulsification of Densiron-68 used in inferior retinal detachment surgery. Eye 2007; 22(1): 152-157.

53 Wong D, Cazabon S, Ali H, Kumar I, Valldeperas X, Groenewald $C$ et al. Can the sequential use of conventional silicone oil and heavy oil be a strategy for the management of proliferative vitreoretinopathy? Ann Acad Med Singapore 2006; 35(3): 181-184.

54 Joussen AM, Kirchhof B, Schrage N, Ocklenburg C, Hilgers RD. Heavy silicone oil versus standard silicone oil as vitreous tamponade in inferior PVR (HSO Study): design issues and implications. Acta Ophthalmol Scand 2007; 85(6): 623-630.

55 Dresp JH, Menz DH. Interaction of different ocular endotamponades as a risk factor for silicone oil emulsification. Retina 2005; 25(7): 902-910.

56 Dresp JH, Menz DH. The phenomenon of 'sticky' silicone oil. Graefes Arch Clin Exp Ophthalmol 2007; 245(6): 863-868. 
57 Wong D, Williams RL, German MJ. Exchange of perfluorodecalin for gas or oil: a model for avoiding slippage. Graefes Arch Clin Exp Ophthalmol 1998; 236(3): 234-237.

58 Scott IU, Flynn Jr HW, Murray TG, Feuer WJ. Outcomes of surgery for retinal detachment associated with proliferative vitreoretinopathy using perfluoro- $n$-octane: a multicenter study. Am J Ophthalmol 2003; 136(3): 454-463.

59 Helbig H, Kellner U, Bornfeld N, Foerster MH. Cataract surgery and YAG-laser capsulotomy following vitrectomy for diabetic retinopathy. Ger J Ophthalmol 1996; 5(6): 408-414.
60 Wickham L, Asaria RH, Alexander R, Luthert P, Charteris DG. Immunopathology of intraocular silicone oil: enucleated eyes. Br J Ophthalmol 2007; 91(2): 253-257.

61 Stolba U, Krepler K, Velikay-Parel M, Binder S. The effect of specific gravity of perfluorocarbon liquid on the retina after experimental vitreous substitution. Graefes Arch Clin Exp Ophthalmol 2004; 242(11): 931-936.

62 Martinez-Castillo V, Boixadera A, Verdugo A, Garcia-Arumi J. Pars plana vitrectomy alone for the management of inferior breaks in pseudophakic retinal detachment without facedown position. Ophthalmology 2005; 112(7): 1222-1226. 